\title{
Limnomermis subtropicalis n. sp. (Nematoda:Mermithidae) a Parasite of Larvae of Simulium orbitale Lutz (Diptera:Simuliidae) in Argentina
}

\author{
L Cristina de Villalobos, Nora B Camino ${ }^{+}$
}

Comisión de Investigaciones Científicas de la Provincia de Buenos Aires, CIC, CEPAVE, Calle 2 No. 584,
1900 La Plata, Argentina

Limnomermis subtropicalis $n$. sp. (Nematoda: Mermithidae) a parasite of Simulium orbitale Lutz (Diptera: Simuliidae) found in Argentina is described and illustrated.

This species is characterized by having medium sized amphids, pocket-shaped, medium sized vagina, sculptured spicule, and by having 9 preanal, 7 postanal papillae in the ventral row, and 12 papillae in the lateral rows.

Key words: Limnomermis subtropicalis n. sp. - Mermithidae - Simulium orbitale - Simuliidae - Argentina

Mermithids parasitizing simulids (Diptera: Simuliidae) in Argentina belong to the following genera: Mesomermis Daday, 1911; Isomermis Coman, 1953; Gastromermis Micoletzky, 1923; Octomyomermis Johnson, 1963; Ditremamermis Camino et Poinar, 1988; and Bathymermis Daday, 1911.

In this paper we report for the first time the presence of the genus Limnomermis Daday, 1911 represented by a parasite of blackflies in Argentina, with the new species $L$. subtropicalis $\mathrm{n}$. sp., found in Misiones province, Argentina.

\section{MATERIALS AND METHODS}

Larvae of Simulium orbitale Lutz were found parasitized by mermithids in Iguazú River, Puerto Iguazú, Misiones, Argentina. The insect larvae were kept in containers with dechlorinated tap water and an airpump at $8^{\circ} \mathrm{C} \pm 2$. Adults and post-parasitic juveniles were observed alive and then killed, by immersing in distilled water at $60^{\circ} \mathrm{C}$ for $2 \mathrm{~min}$, fixed in TAF: formalin ( $40 \%$ formaldehyde) $7 \mathrm{ml}$, triethanolamine $2 \mathrm{ml}$ and distilled water $91 \mathrm{ml}$ (Courtney et al. 1955) and processed to glycerol-ethanol by Seinhorst's method (Seinhorst 1959) for taxonomic studies. Transversal sections were made by hand and prepared in glycerine jelly (Hooper 1970). Drawings and measurements were made from live and fixed specimens with a camera lucida connected to a Zeiss light microscope. Measurements (in micrometres) are for the holotype male and allotype female and for paratypes the range is in parenthesis.

\footnotetext{
${ }^{+}$Corresponding author. Fax: +54-21-232327

Received 24 September 1996

Accepted 3 March 1997
}

\section{DESCRIPTION}

\section{Limnomermis Daday, 1911}

Type species: Limnomermis limnobia Daday, 1911 Cuticle thin without visible crisscross fibres. Six cephalic papillae. Hypodermal chords six. Lateral chords have two to three rows of cells. Mouth terminal and shifted ventrally. Amphids small, more rarely large, oval-pyriform. Tail in both sexes blunt or pointed. Spicule one, relatively short, the tip of the spicule sometimes sculptured. Vagina cylindrical and slightly S-shaped.

\section{Limnomermis subtropicalis $\mathrm{n}$. $\mathrm{sp}$.}

(Figs 1-8)

Medium sized nematodes. Cuticle without crisscross fibres visible under light microscope. Six cephalic papillae. Amphids medium sized, pocketshaped. Six hypodermal chords present all along the body: lateral chords containing three rows of cells each, dorsal and ventral chords with one row of cells each one, subventral chords containing two rows of cells. Mouth terminal and shifted ventrally. Vulva protruding, vulval lips developed. Vagina Sshaped and muscular. One spicule, medium sized and sculptured. Three rows of genital papillae: the ventral row has 9 preanal and 7 postanal papillae, the subventral rows with 12 papillae each. Both sexes with long, thin and pointed tail.

Male: $(n=12)$. Body length: 10.400 (8.70011.400); width of head at level of cephalic papillae: 42.6 (40-44); width of body at level of nerve ring: 71.4 (70-73); greatest width of body: 84 (76-92); distance from anterior end to nerve ring: 180 (164-200); distance from anus to tail: 134 (124-144); length of the spicule: 90 (88-96); width of spicule in the middle: 11 (11-12.5); length and width of amphids: 16x12. 


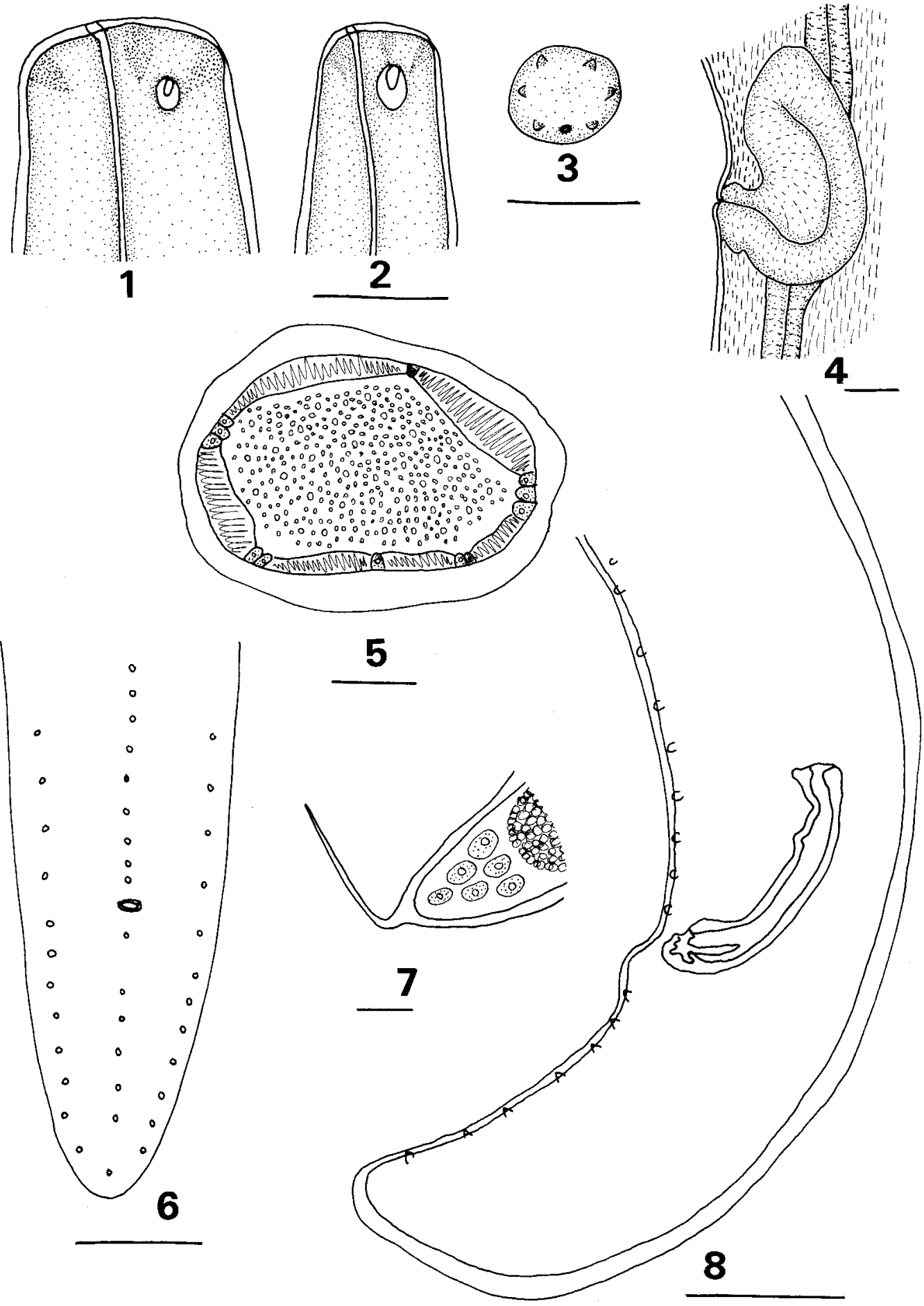

Limnomermis subtropicalis n. sp. Fig. 1: head of the female in lateral view. Fig. 2: head of the male in lateral view. Fig. 3: apical view of male head. Fig. 4: vagina in lateral view. Fig. 5: cross section at midbody. Fig. 6: ventral view of male tail. Fig. 7: post-parasitic juvenile tail in lateral view. Fig. 8: lateral view of male tail (Bars $=50 \mu \mathrm{m})$. 
Female: $(\mathrm{n}=15)$. Body length: $17.340(16.370-$ 18.520); width of head at level of cephalic papillae: 70.5 (68-73); width of body at level of nerve ring: 98 (88-107); greatest width of body: 231 (190-272); width of body at level of vulva: 236 (232-240); width of body at level of posterior end of trophosome: 146 (136-156); distance from head to nerve ring: 224 (204-240); length of vagina: 252 (244-260); width of vagina: 83.5 (82-84); V: 50\% (49-50.5); length and width of amphids: $12 \times 8$.

Post-parasitic juveniles: $\mathrm{n}=10$. Tail appendage long, thin and pointed. Mean length 144 (138-150).

Eggs: oval with smooth shell, unembryonated, without any additional covering. 58 (56-60) x 38 (3640).

Type host: larvae of Simulium orbitale Lutz (Diptera: Simuliidae). det. Dr Sixto Coscarón, Museo de La Plata.

Type locality: Iguazú River, Puerto Iguazú, Misiones Province, Argentina.

Type material: holotype male, allotype female and paratypes are deposited in the Centro de Estudios Parasitológicos y de Vectores (CEPAVE), Division Entomonematodes, Argentina. Series numbered M0123-M0125.

\section{REMARKS}

The new species $L$. subtropicalis $\mathrm{n}$. $\mathrm{sp}$. has a sculptured spicule typical of two other species of the genus Limnomermis Daday, 1911, namely: $L$. angustifrons Rubzov, 1974, from USSR and the host unkown; and L. fluviatilis (Hagmeier, 1912), from Germany and parasitizing chironomids.

L. angustifrons differs from our new species by the long spicule $(190 \mu \mathrm{m})$, the genital papillae numerous: 49 papillae in medial row, of which 16 are postanal, lateral rows have approximately 30 papillae each, and it has a long vagina $(800 \mu \mathrm{m})$.

L. fluviatilis is characterized by the short spicule $(66 \mu \mathrm{m})$, oar-shaped, surface of spicule with longitudinal hexahedral cells, which become shorter at the end and merge with each other, the amphids are very large and the ventral row of genital papillae in the male has 8 preanal and 7 postanal papillae.
The other species of the genus found in Argentina is L. bonaerensis Camino, 1989, a parasite of amphipods (Crustacea). It can be separated from our new species by having the spicule not sculptured, the vagina long $(150 \mu \mathrm{m})$ and by the number of the genital papillae, in which 12 are pre and 12 postanal; 28 papillae are in the lateral rows.

L. subtropicalis $\mathrm{n}$. $\mathrm{sp}$. is characterized by having medium sized amphids, pocket-shaped, medium sized vagina, spicule sculptured; it has 9 pre, 7 postanal papillae, and 12 papillae in lateral rows.

\section{REFERENCES}

Camino NB 1989. Limnomermis bonaerensis sp. n. (Nematoda, Mermithidae), parásita de anfípodos (Crustacea, Malacostraca) en Argentina. Rev Ibér Parasitol 49: 227-231.

Camino NB, Poinar Jr GO 1988. Ditremamermis simuliae gen. n. sp. n. Nematoda:Mermithidae), parásito de Simulium bonaerense Coscarón y Wygodzinsky en Argentina. Neotrópica 36: 93-97.

Coman D 1953. Mermithide freatice in fauna Republicii Populare Romine. Studii si Cercetâri Stiint (Akad RPR Cluj) 6: 96-106.

Courtney WD, Polley D, Miller VL 1955. TAF, an improved fixative in nematode technique. Pl Dis Reptr 39: 570-571.

Daday E 1911. Adatok a Mermithidae család édes vizden élö fajainak ismeretéhez. Math Term Ertesito Budapest 29: 450-514.

Hagmeier A 1912. Beiträge zur Kenntnis der Mermithiden. I. Biologische Notizen und systematische Beschreibung einiger alter und neuer Arten. Zool Jahrb 32: 521-612.

Hooper DJ 1970. Handling, fixing, staining and mounting nematodes. In JF Southey, Laboratory methods for work with plant and soil nematodes. HMSO London MAFF Tech Bull 2: 39-54.

Johnson AA 1963. Octomyomermis itascensis gen. et sp. nov., a parasite of Chironomus plumosus (L.). Trans Amer Microscop Soc 82: 237-341.

Micoletzky H 1923. Mermithiden und freilebende Nematoden aus dem Grundschlamm des Attersees in Oberösterreich. Zool Anz 55: 239-245.

Rubzov IA 1974. Aquatic Mermithidae of the fauna of the USSR. Nauka, Leningrad, $274 \mathrm{pp}$.

Seinhorst JW 1959. A rapid method for the transfer of nematodes from fixative to anhydrous glycerin. Nematol 4: 67-69. 
342 New Species of Mermithids Parasite of Simulid - LC de Villalobos, NB Camino 